\title{
IN MEMORIAM: SHIRLEY JOWSEY, 1920-2014
}

Earl and Verda Upshall, Box 475, Saltcoats SK SOA3R0. Email: veupshall@xplomet.ca

Ida "Shirley" Jowsey, beloved wife of Dr. J.R. (Jim) Jowsey of Saltcoats, Saskatchewan joyously celebrated her $94^{\text {th }}$ birthday with friends in Saltcoats on 29 January, but took ill on February 2, 2014, and died that evening at the Yorkton Regional Health Centre.

Shirley was born January 29, 1920 at Antelope, Saskatchewan, the daughter of Ivar and Margaret (nee: Langford) Sather. She grew up a "tomboy," who loved the outdoors, the sweep of the prairie, the abundant life found in sloughs and creeks, the panoramic night skies, the gentleness and the raw power of the natural world.

In the late twenties and early thirties, Shirley's family lived in Colgate, Saskatchewan. In 1939, the family moved to Star City where Shirley ran the projector at the local theatre. During the war years, Shirley worked at a munitions factory and a float coat factory in Ajax, Ontario. After the war she moved to Weyburn as a theatre projectionist before relocating to Regina where she worked for 16 years at Darke Hall Music Conservatory as a bookkeeper.

During a Nature Saskatchewan Meeting, she met James Jowsey, whom she married July 15, 1969. The couple lived and worked in Regina and in 1977 produced the first edition of the botanical best-seller, Wildflowers Across the Prairies, by Fenton Vance, Jim Jowsey and

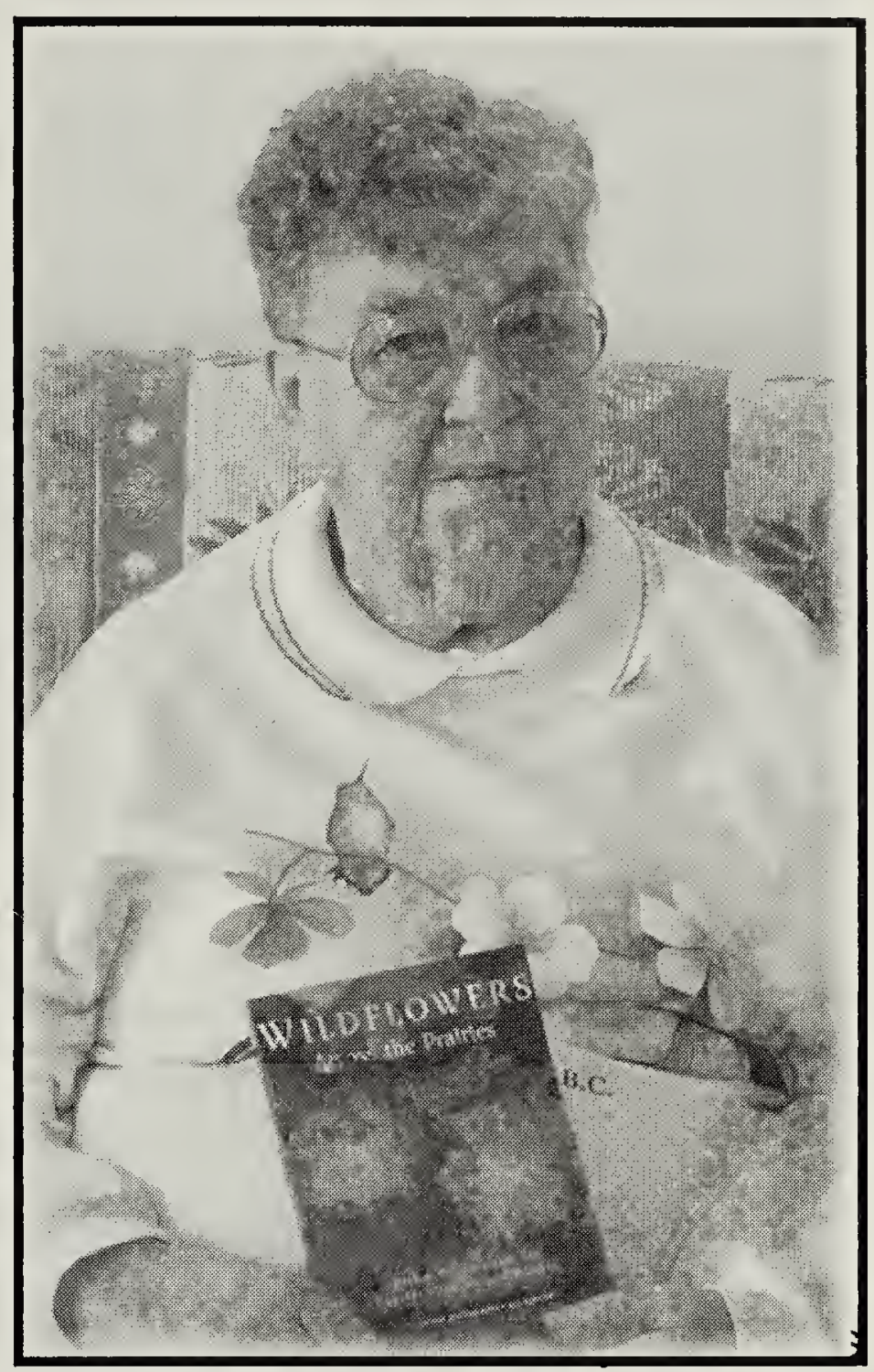

typist, using a standard typewriter; when a single error was detected or a small insertion indicated, she had to retype that entire page. She was also editor and proofreader; the book included her field photo of the Dotted Blazingstar. The acknowledgement reads: "The role of Shirley Jowsey in the development of this book has involved contributions of skill, wisdom, and commitment substantially equivalent to that of the authors." A revised, expanded and even more successful edition by the same three authors appeared in 1984 , with the addition of 112 species, 654 colour photographs and a fullyindexed plant family key, all typed by Shirley on a standard typewriter. In 
1985, Jim and Shirley retired, moving to the Jowsey farm north of Saltcoats. Fenton Vance died in 1997, aged 90. In 1999, Jim and Shirley brought out a third edition, leaving the plant pages and photographs unchanged, but adding Frank Switzer as fourth author to write the new section on grasses, sedges and rushes, which he keyboarded into a computer.

From the farm, Jim and Shirley often led formal and informal nature and historical excursions, locally and across Saskatchewan. They loved to pack lunches and head out for an excursion. Shirley was one of the main organizers and promoters for several years of Nature Sask excursions such as those to Cypress Hills and Porcupine Plain. She and Jim also made visits to Churchill and the tundra; a highlight for her was a trip to Norway and other Scandinavian countries, and the time spent some winters in Victoria, B.C. For many years she organized, collated and submitted statistics for the Christmas and other Bird Counts. She was a life member of Nature Saskatchewan and a charter member of the YFBTA (Yellowhead Flyway Birding Trail Association) formed in 2003, and a Board member since that time. Shirley was always a staunch supporter and mentor for students hired by YFBTA to lead their summer student program from 2010-2012.

Shirley was an active member of Saltcoats United Church - on Session for many years, a member of the United Church Women, and a generous supporter of St. Andrew's College at the University of Saskatchewan, Calling Lakes Centre and special church programs. Shirley was a lifelong learner, who appreciated Open University and University Extension Programs. Most recently, Shirley enjoyed her participation in the Laketown Leaders, always ready for another potluck, an afternoon of canasta and some visiting.

Shirley was predeceased by her parents, Ivar and Margaret Sather; brothers, Murray and Donald and one infant brother, Raymond; brotherin-law, John Jowsey. She leaves to mourn her passing and celebrate her life, her husband Jim; step children, Harriet Pepper and Harold Jowsey; brother, Milton; brotherin-law, Hugh Jowsey; sister-in-law, Mildred Jowsey; - as well as nieces and nephews.

A Memorial Service was held Tuesday, February 11, 2014 from the Saltcoats United Church in Saltcoats, with Reverends Walter Farquharson and Thom Carnahan officiating. The organist, Ruth Datema, and members of the Saltcoats United Church Choir and Friends led the hymns. Cremation Committal followed in the Saltcoats Town Cemetery.

We thank Christie's Funeral Home, Walter Farquharson and Stuart Houston for their assistance in preparation of this memorial. 